\title{
Marketing Analysis of Processed Fishery Products using Interactive Media
}

\section{Verderika Ndatangara ${ }^{1}$, Mardiana Erthrawaty Fachry ${ }^{2}$, Sri Suro Adhawati ${ }^{2}$}

\author{
${ }^{1}$ Student of Master Degree Fisheries Science, Faculty of Marine and Fisheries Science, Hasanuddin University, Perintis Kemerdekaan \\ St.Km 10, Makassar 90245, Indonesia \\ ${ }^{2}$ Department of Fisheries Science, Faculty of Marine and Fisheries Science, Hasanuddin University, Perintis Kemerdekaan St Km 10 , \\ Makassar 90245, Indonesia \\ *Email: $\underline{\text { kkhaverderika@gmail.com }}$
}

\begin{abstract}
This study aims to analyze marketing of processed fishery products by using interactive media in Makassar conducted in April - June 2019 took place in the city of Makassar. Data was collected through interviews, observations, questionnaires and literature study. The research method in this study is a descriptive analysis will present a general overview of SMEs marketing of processed fish products as a whole by focusing on marketing by using interactive media. Samples are processed fishery products 8 SMEs located in the city of Makassar with criteria using the owners use at least 2 social media and has been operating for less than 5 years. The results showed that social media are the most widely used in the sales activity (75\%) is WhatsApp, Facebook and Instagram. Group 2 media (12.5\%) only uses WhatsApp and Facebook and group 4 media (12.5\%) using WhatsApp, Facebook, Instagram and Line.. The percentage of consumers prefer buying fishery products in a row is a promotion, place, price and product.
\end{abstract}

Keywords—Fishery Products, Promotion Mix, Interactive Media, Digital Marketing

\section{INTRODUCTION}

Fishery product processing business is one part of the Agroindustry expected strong competitive and able to survive in a relatively long period of time. But in the era of free trade or globalization requires companies fisheries improve productivity and product quality that still exist in the competition. Therefore, in the development of enterprises, especially SMEs required in order to plan or formulate a proper strategy to improve the business management system (Pranowo 2015). Ibrahim et al., (2013), business continuity seen from the economic dimension, one of the economic driver direct business are market opportunities, production and marketing costs. Alma (2013) explains that marketing management is a process to improve the efficiency and effectiveness of marketing activities undertaken by individuals or by companies.

The fact that the field show most SMEs in Indonesia, has some of the same problems, one of which is the lack of knowledge about marketing, due to the limited information that can be reached by SMEs on the market. Setiwati (2014) suggested the research results (Effect of E-Marketing In Online Business Using Social Media) that Online Marketing Strategy positive effect on earnings of Micro, Small and Medium Enterprises (SMEs) in Central Java. Siswanto, (2013) describe the presence of social media with all its advantages and proven to provide facilities that are not less interesting than any other media that requires a high cost in use. If optimal, social media can create a brand image (brand image) for SMEs and satisfaction that will have an impact on loyalty.

The accessibility and interactivity of the Internet to bring dramatic changes in the paradigm of conventional marketing. Internet changing the way organizations to design, processing, manufacture, market, and deliver the product. Wider scope of competition also requires integration and coordination between the departments of information, marketing, customer service and other departments. (Chandra, Greorius., Fandy Tjiptono. 2012). At present, the world economy, especially developing countries such as Indonesia, are moving towards a digital economy. Technological developments into the first drive these changes. The world organization OECD (Organization for Economic Cooperation and Development) said that digital innovation is claimed to bring countries closer to sustainable prosperity (Kurniawan, 2017).

The survey results Indonesian Internet Service Provider Association (APJII) internet penetration in Indonesia throughout 2017. Figures internet penetration has increased over the previous year, an increase of approximately 54.68 percent or touch the figure of 143.26 million users through a variety of devices (APJII, 2018) It is an opportunity and an advantage in marketing the 
processed fishery products. The use of social media right and true will to minimize time and earn more profits. Theresia Pradiani (2017) describe an increase in orders from consumers by sales using social media. However, the use of social media still need to be developed to make innovations in promoting cottage industry results to be more interesting. Thus, through this research is expected to provide an overview of the development of marketing strategies for businesses of processed fishery products so that it can continue to compete in the future.

\section{RESEARCH METHODS}

This research was conducted for 3 months, from April to July 2019 in the city of Makassar. In this research using descriptive analysis will present a general overview of processed fishery products marketing of micro small and medium enterprises (SMEs) as a whole by focusing on marketing by using interactive media. And to determine consumer response to marketing acceptance of processed fishery products used questionnaire (via google forms). Samples have $8 \mathrm{UMKM}$ with criteria located in the city of Makassar, has been operating less than 5 years and Owner actively using social media at least 2 which include YouTube, Facebook, Whatsapp, Instagram, Line \& Twitter.

\section{III. RESULTS \& DISCUSSION}

\section{A. Product Marketing Micro Small Medium Processed} Fishery Products in Makassar

1. Product and price

Every small and medium micro enterprises processed fishery products in Makassar has many product variants. Among them there are products that must be processed again for consumption and there are direct consumption. There are different variants of foods and beverages such as fish balls, nuggets fish, "otak-otak", bull without thorns, seaweed crackers, crackers squid, fruit syrup seaweed and others. Here are details of the main products and at what price.

Table 1. Types of products and prices for micro and small and medium enterprises processed by fishery products

\begin{tabular}{llccc}
\hline Group & Main Product & UMKM & (g) & Price(Rp) \\
\hline Food & Abon Tuna & J1 & 250 & 25.000 \\
& Abon Gabus & J2 & 100 & 35.000 \\
& Abon Tiara & J3 & 130 & 25.000 \\
& "Otak-otak" & J4 & 900 & 120.000 \\
& Otak-otak & J5 & 250 & 500.000 \\
& desniel & & & \\
Snacks & Squid crackers & J6 & 80 & 15.000 \\
& Seaweed & J7 & 300 & 35.000 \\
& crackers & & &
\end{tabular}

Drink passion fruit J8 $\quad 500$ 35.000 syrup seaweed

Source: Primary Data, 2019

\section{Social Media}

Social media pointed out that in January this year 2017 Indonesia ranked third as the world's largest social media users. Social media users in Indonesia reached 27 million users and increased as much as $34 \%$. It is evident that Internet users in Indonesia use sosial media means to obtain the necessary information. WeAreSocial.net \& Hootsuite In 2017, the development of Internet usage in Indonesia is very rapid, which grew $51 \%$ within one year. With a growth rate that far exceeds the growth rate of Internet usage in the world, namely $10 \%$, Indonesia ranks second biggest internet users universal. The percentage of Internet users who use each platform (based survey) is as follows: Youtube: $88 \%$, Whatsapp: $83 \%$, Facebook: $81 \%$, $80 \%$ of Instagram

With the information technology network connected to the global Internet provide opportunities in marketing products or services. Internet and networking features interesting social media applications is one of the promotional tools are better and cheaper, especially in running a business or businesses. In addition to using a mobile phone, some SMEs which are already used more than two social media.

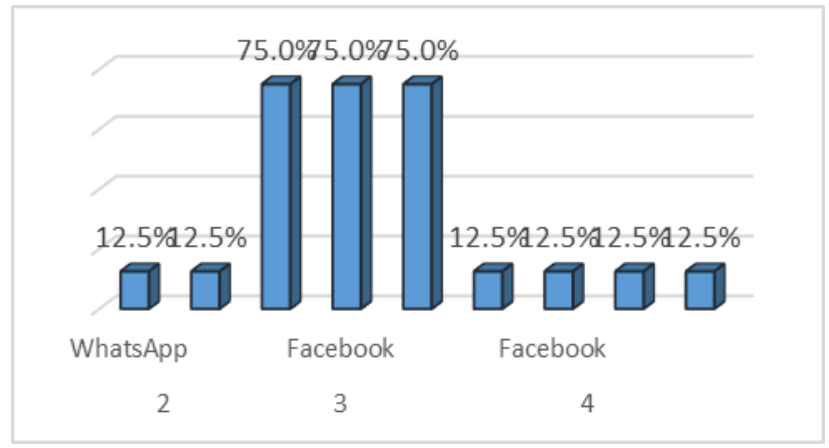

Fig 1. Percentage usage of social media in small and medium micro enterprises processed fishery products in Makassar

The results showed that each manager of SMEs do not use all the social media (6) in promotional activities. Group 3 Media are the most widely used (75\%) that is Whats App, Facebook and Instagram. Group 2 media (12.5\%) only uses Whats App and Facebook and group 4 media (12.5\%) using Whats App, Facebook, Instagram and Line. Here the percentage of active social media use of micro and small and medium enterprises in the city of Makassar in promotional activities of processed fishery products

\section{B. Percentage increase in sales}


The sales volume of the sales expressed in number of sales amount of physical force or the amount of money that must be achieved. In a company marketing objective is to increase the volume of profitable sales to generate revenue within the meaning optimally and increase profits. The sales volume is a measure that indicates the number or size of the amount of goods or services sold. The following graph average sales before and after the use of social media on SMEs processed fishery in Makassar.

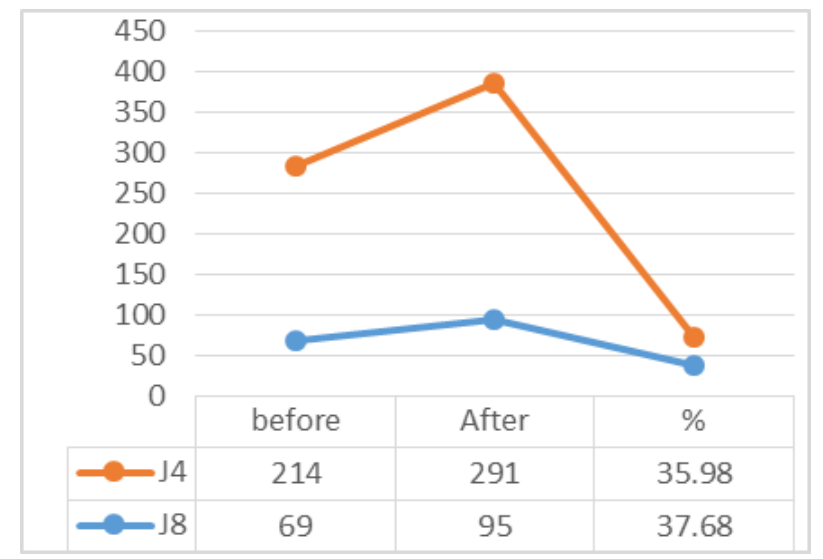

Fig 2. Percentage increase in sales in J4 and J8 SMEs.

The results showed an increase only in two SMEs. Of the average sales before and after the use of social media use social media there was an increase of Sales. At J4 and J8 SMEs increased by $37.68 \%$ and $35.98 \%$. J4 on SMEs SMEs and MSMEs using three media J8 using four media.

\section{Response and consumer acceptance}

1. The use of social media on consumer

One key to success for all businesses is to get to know its customers more closely. Social media makes it easier recognition process than before. Basically, social media has changed the way consumers interact and how companies market their products. The presence of social media as a channel of communication can help process transactions quickly. Here's an overview of social media are used by consumers in buying processed fishery products in Makassar

Basically, social media has changed the way consumers interact and how companies market their products. The presence of social media as a channel of communication can help process transactions quickly. Here's an overview of social media are used by consumers in buying processed fishery products in the city of Makassar.

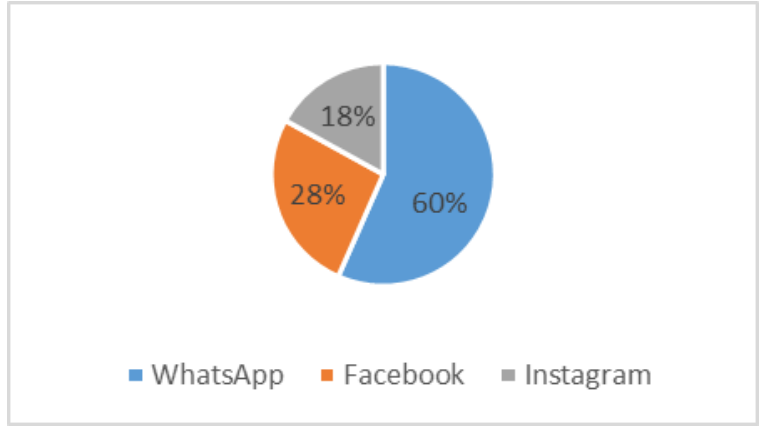

Fig 3.Percentage of social media use in consumer products processed fishery

Research, social media are the most widely used $60 \%$ is whatsapp, a social media interaction which most consumers utilize to communicate in order to get a quick response. However some consumers find privacy in buying the product and feel simply by using social media (Facebook and Instagram) as a promotion manager in the transaction. the second largest is Facebook (28\%) and the last is Instagram (18\%).

2. Response and consumer acceptance of the purchase processed fishery products.

Sumarwan also promoted (2014:377) consumer purchasing decisions are decisions that include consumer decisions about what to buy, whether to buy or not, when to buy, where to buy and how to pay for it. It should be considered before making a purchase decision is the desire that has been rounded to buy the product. And Zanjabila (2017) proved that social media marketing significantly influence purchasing decisions.

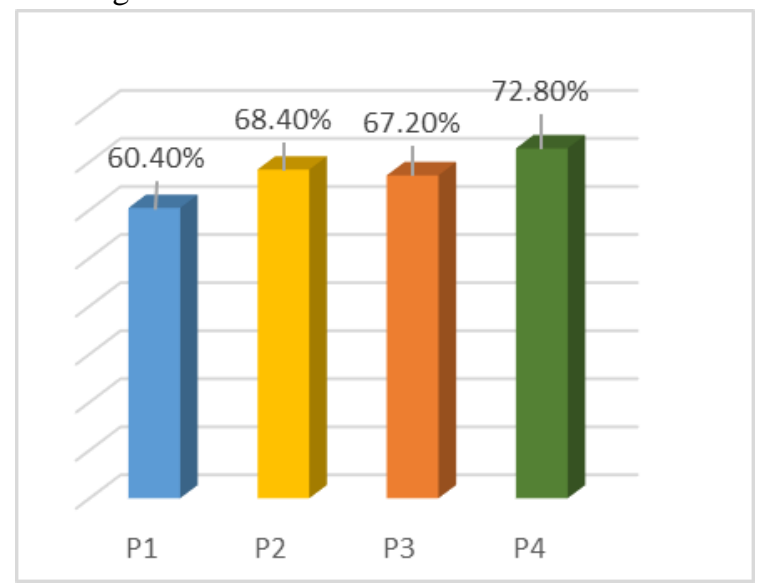

Fig 3. Percentage of reasons consumers buy products Fishery

The diagram shows that the main reason for the Promotion of $72.80 \%$ while among sellers use social media, has good reviews and is promoted by the account reliable. $68.40 \%$ choose the place and $67.20 \%$ and $60.40 \%$ product price for good taste, standardization of products, form an attractive logo and brand famous. In (Erawati, 2015) states that the 
promotion influential on purchase decisions in accordance with the opinion of Alma (2013: 181) which is the main purpose of the campaign is to inform, attract, and then influence the increase in sales. A promotional activity if done properly can affect consumers about where and how consumers spend their opinions.

\section{CONCLUSION}

The marketing activities of micro and small and medium enterprises in fishery products processed in Makassar using interactive media show that not all social media are used in promotional activities. Social media is Whatsapp and Facebook Instagram 33.3\% and 29.20\% of the most widely used, Line $4.20 \%$ and $0 \%$ Youtube and Twitter. The results indicate an increased percentage of sales only on 2 SMEs. The percentage of consumers prefer buying fishery products in a row is a promotion, place, price and product.

\section{REFERENCES}

[1] Alma, Buchari. Marketing Management and Marketing Services. Bandung: Alfabeta, 2013

[2] APJII. 2017. The behavior of Indonesian Internet Users Association, 2017 Indonesian Internet Service Provider

[3] Erawati, Pungky. 2015 Marketing Mix Analysis on purchasing decisions healthy meatballs meatballs atoms. Agribusiness Study Program Faculty of Science and Technology State Islamic University Syarif Hidayatullah Jakarta

[4] Kurniawan, S. (2017, February 20). Opinion: Marketeers. Retrieved from Marketeers: http://marketeers.com

[5] Pradiania, Theresia. 2017. Effect of Digital Marketing Systems Marketing to Sales Volume Increased Results The housing industry. Journal of Jibeka, Vol 11 No. 2 Feb: 4653

[6] Pranowo, Asmo Purbo. 2015. Marketing Strategy for Poklahsar Level Tuna Processed Products in the Maritime and Fisheries Industry Framework in Pacitan Regency. Master of Management faculty of economics and business. University eleven March Surakarta..

[7] Siswanto, Tito. 2013 Social Media Optimization as a Marketing Media Small and Medium Enterprises, Liquidity Journal, vol 2, no 1, 80-86

[8] Sumarwan, Ujang. 2014. Consumer Behavior: Theory and practice in marketing. Bogor: Ghalia Indonesia

[9] Tjiptono, Fandy and Gregorius Chandra. 2012. Strategic Marketing. Yogy akarta, ANDI

[10] Wahyuni, Sri (2014). Analysis of online promotion strategy on pasarhosting.com. Faculty of Economic and Management Bogor Agricultural University.

[11] Zanjabila, Ridwan. 2017. Analysis of Effect of Social Media Marketing on purchasing decisions (study no customers BandungTechno Park 2017). Scientific Journals Faculty of Applied Sciences, University of Telkom. Vol.3. No. 2 p. $368-375$ 